\title{
Quantitative ultrastructural analysis of the human parietal cell during acid inhibition and increase of gastric potential difference by glucagon
}

\author{
K J IVEY ${ }^{1}$, A TARNAWSKI ${ }^{2}$, D SHERMAN, W J KRAUSE, K ACKMAN, \\ M BURKS, AND J HEWETT
}

From the Departments of Medicine and Anatomy, Harry S. Truman Memorial Veterans Medical Center and the University of Missouri Medical Center, Department of Statistics, University of Missouri, Columbia, Missouri, USA

SUMMARY Glucagon inhibits gastric acid secretion and increases the negativity of gastric mucosal potential difference (PD) in man. To test the hypothesis that the increased negativity of PD after glucagon in man could be due to decreased parietal cell canalicular membrane area, a quantitative ultrastructural analysis was carried out. Four healthy volunteers with normal gastric mucosa were submitted to biopsy before and 20 minutes after intravenous injection of $2 \mathrm{mg}$ glucagon (G). This time corresponded with the maximal change in PD and a decrease in gastric acid secretion. Canalicular and tubulovesicular membrane area of 80 parietal cells ( 40 cells before glucagon and 40 cells after glucagon) were quantified by the Loud morphometric method. After glucagon, the oxyntic cell canalicular membrane area was reduced by one-fourth $(P<0.05)$, while tubulovesicular membrane area showed an increase $(\mathrm{P}<0.05)$ at the same time. The decrease in the area of parietal cell canalicular membrane caused by glucagon may in part be responsible for increased negativity of the gastric PD caused by this hormone.

In previous studies (Tarnawski et al., 1978a,b), we have reported a significant increase in negativity of gastric mucosal potential difference (PD) in man after administration of the acid-inhibitory hormone, glucagon.

Qualitative (Vial and Orrego, 1960; Sedar and Friedman, 1961; Helander, 1964) and quantitative (Frexinos et al., 1971; Helander and Hirschowitz, 1972; Helander et al., 1972) ultrastructural studies have demonstrated that resting parietal cells undergo characteristic changes on stimulation to secrete acid. In piglets, Forte et al. (1977) reported a fall in PD (decrease in negativity) after histamine stimulation that was associated with a marked qualitative increase in the canalicular component of the parietal cell secretory surface. They postulated that the decreased negativity of PD after histamine was due to the increased canalicular membrane area which

\footnotetext{
${ }^{1}$ Address for reprint requests and correspondence: $\mathrm{K}$. J. Ivey, MD, Department of Medicine, University of Missouri, Columbia, Missouri 65212, USA.

${ }^{2}$ Present address: Dr A. Tarnawski, Department of Gastroenterology, Medical Academy, Krakow, Poland.

Received for publication 31 July 1979
}

lowered electrical resistance to ion movement. The converse of this would apply if inhibition of acid secretion was associated with decreased canalicular membrane area and raised PD.

Previous studies of antisecretory agents on parietal cell ultrastructure have been done after stimulation with a secretagogue. In these studies, the expected formation of microvilli and the increase in surface area of canaliculi was inhibited by most agents. These include qualitative studies with $2: 4$ dinitrophenol, an oxidative uncoupling agent (Vial and Orrego, 1963), acetazolamide, an inhibitor of carbonic anhydrase (Sedar, 1962), glycopyrrolate, an anticholinergic (Posey et al., 1968), and UK-9040, an antihistaminic derivative (Hamer et al., 1977). Using stereological analysis, Zalewsky and Moody (1977) showed that the $\mathrm{H}_{2}$ receptor antagonist, cimetidine, decreased secretory membrane surface area during acid inhibition. In contrast, thiocyanateinhibited parietal cells showed no significant decrease in secretory membrane area, although luminal acid secretion decreased (Zalewsky and Moody, 1977).

The aim of the present study was to determine if glucagon affected the ultrastructure of parietal cells 
in man so as to test the hypothesis that increased negativity of PD after glucagon in man could be due to decreased parietal cell canalicular membrane area.

\section{Methods}

\section{SUB JECTS}

Studies were performed on five healthy subjects, aged 21 to 27 years. The study was approved by the Institutional Human Experimentation Committee, and all the subjects gave informed consent.

Studies were of two types: physiological, where gastric PD was recorded, and morphological, where gastric biopsies were taken. The physiological findings of the effect of glucagon on PD and gastric $\mathrm{pH}$ have been reported previously (Tarnawski et al., 1978b). In both studies, $2 \mathrm{mg}$ glucagon (Eli Lilly and Company, Indianapolis, Indiana) were administered in a single intravenous injection given over three minutes.

\section{POTENTIAL DIFFERENCE}

Gastric mucosal PD was measured by a wellestablished technique (Andersson and Grossman, 1965) using intravenous and intragastric electrodes filled with a saturated $\mathrm{KCl}$ solution in $3 \%$ agar, as described in previous studies (Baskin et al., 1976). Continuous PD recordings were made by means of a strip chart recorder.

Fasting gastric contents were aspirated at the beginning of each study. $\mathrm{pH}$ was determined with a Beckman Expandomatic pH meter (Beckman Instruments, Inc., Fullerton, California). The stomach was washed with $200 \mathrm{ml}$ normal saline, aspirated, a fresh $100 \mathrm{ml}$ saline instilled, and PD recording begun to establish a basal control period of 30 minutes. Glucagon $(2 \mathrm{mg})$ was then injected intravenously over a three minute period. The first gastric sample after glucagon injection was taken at 15 minutes. Gastric aspiration and instillation of saline was then repeated at 30-minute intervals. Gastric aspirates were measured for $\mathrm{pH}$.

\section{GASTRIC MUCOSAL BIOPSIES}

The above studies were repeated in five subjects one week after the PD recording to obtain biopsy samples. PD was not recorded during the biopsy studies.

Biopsies were performed using a Quinton $\mathrm{Hy}$ draulic Biopsy Tube (Quinton Instruments, Seattle, Washington) positioned under fluoroscopic control in the stomach fundus near the greater curvature (Baskin et al., 1976). Biopsies (2-3 mm in diameter) were obtained for light and electron microscopy during the basal control period and 20 minutes after glucagon injection. The timing of the biopsies was chosen to coincide with maximum change in gastric PD occurring after glucagon injection in order to correlate ultrastructural and electrophysiological data (Fig. 1).

TISSUE PREPARATION

Biopsies were fixed for two hours in $3.5 \%$ purified glutaraldehyde buffered in $0 \cdot 1 \mathrm{M}$ phosphate to $\mathrm{pH} 7 \cdot 4$ in the cold. Tissues were washed with buffer and post-fixed in $1 \%$ osmium tetroxide at $0^{\circ} \mathrm{C}$ for one hour. Specimens were dehydrated in a graded series of ethyl alcohol solutions and embedded in a mixture of five parts Epon resin (6 parts A to 4 parts B resin mixtures) (Luft, 1961) to 4 parts Spurr lowviscosity embedding resin (Spurr, 1969). Thick sections of this material, cut at 0.5 to 2 microns, were stained with toluidine blue and examined by light microscopy.

For electron microscopy, silver-grey thin sections from specimens of an approximate size of $\frac{3}{4} \times 1 \frac{1}{2} \mathrm{~mm}$

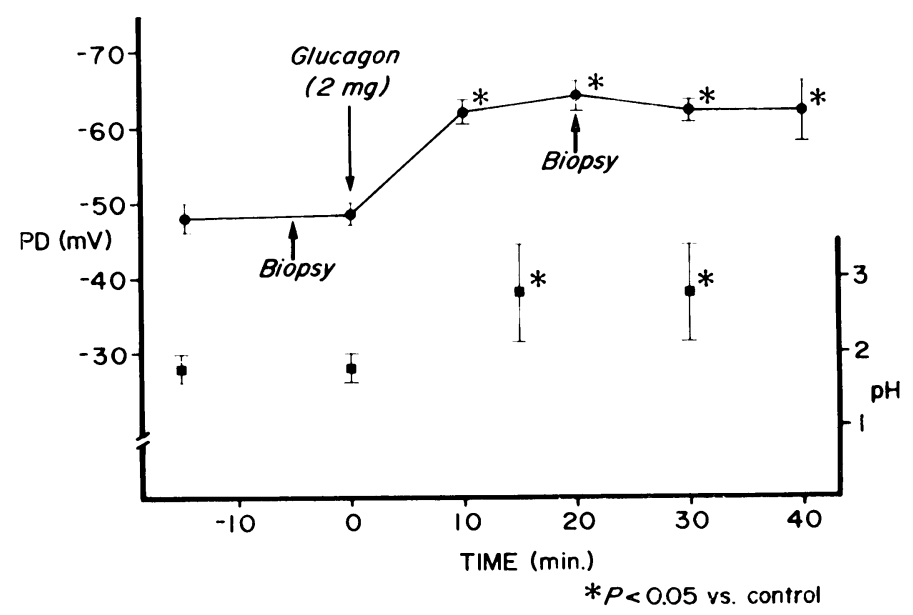

Fig. 1 Effect of glucagon injection on gastric $P D$ and $p H$. Values are mean t-SEM on vertical axis. $P D$ is expressed in terms of negative $m V$, the luminal gastric mucosa being negative with respect to the blood. All PD values 10 minutes after glucagon injection were significantly greater (increase in negativity of $P D)$ than control values. The $p H$ values at 15 and 30 minutes were significantly greater than control pH values. 
were mounted on uncoated grids having parallel bars (200 line/in.) orientated so that the mucosal surface was parallel to the bars. The grid bars clearly define regions of the gastric glands in relationship to the mucosa surface. Sections were double-stained with $2 \%$ uranyl acetate (Watson, 1958) followed by lead citrate (Reynolds, 1963) and examined in a Phillips 300 electron microscope, operated at $60 \mathrm{kV}$.

QUANTITATIVE METHODS

Cells selected for morphometric analysis were of uniform diameter, with nuclei occupying at least $3 \%$,

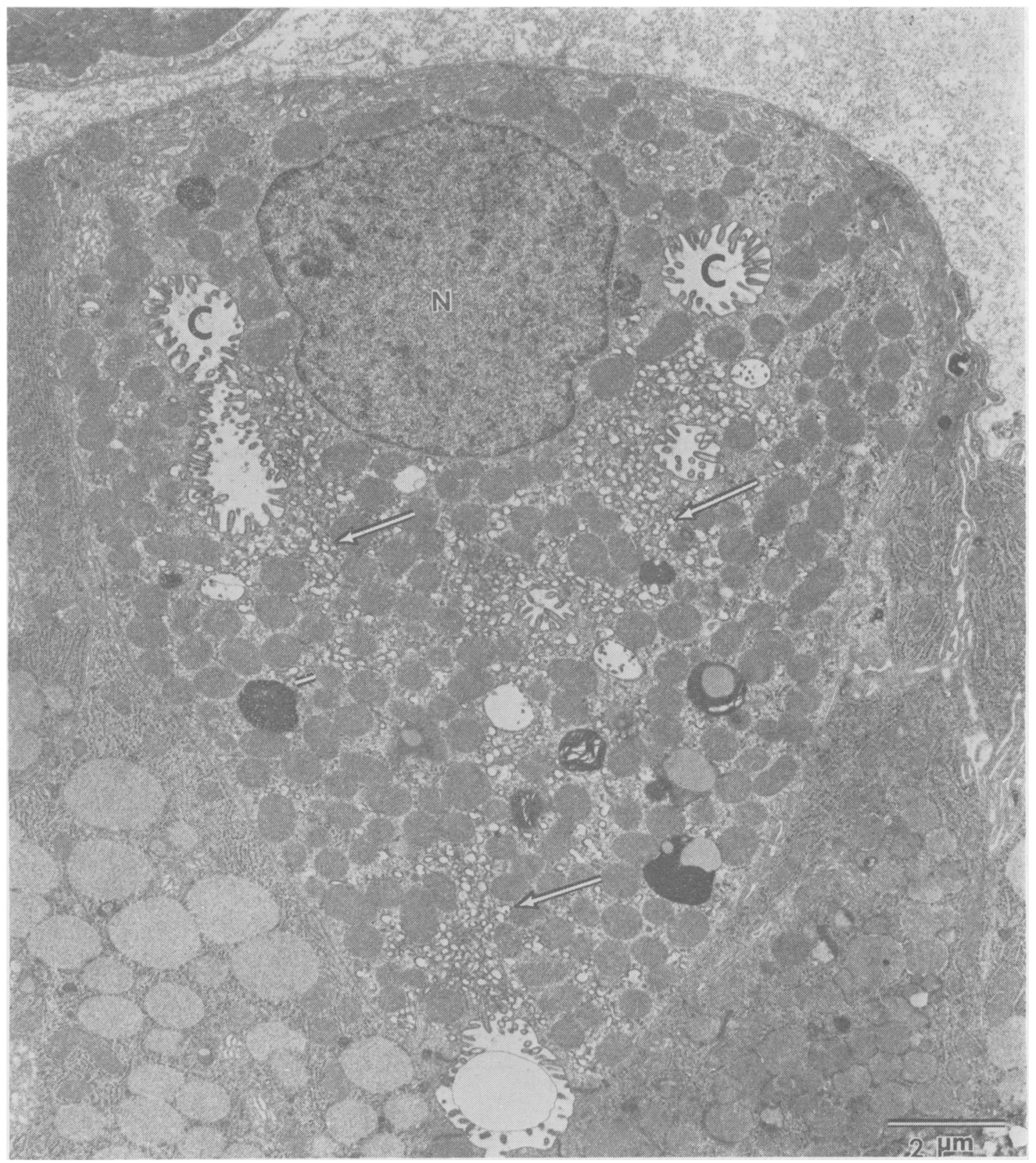

Fig. 2 A parietal cell from human stomach 20 minutes after intravenous administration of glucagon. The distribution of the tubulovesicular components (arrows) and the relative size and shape of the canaliculi $(C)$ are shown. $\times 8250$. 
but no greater than $25 \%$, of the cell area. Cells were taken evenly from five different levels of the gastric gland, since position differences were noted in another study (Frexinos et al., 1971). Electronmicrographs of 20 cells were taken from each of four subjects-10 before and 10 after glucagon injection. In the fifth subject, biopsy material was technically inadequate and therefore not quantified. A total of 80 micrographs -40 before and 40 after glucagonwas available for final analysis.

Tubulovesicular and canalicular membranes were quantified according to the Loud quantitative (twodimensional) method (Loud, 1962; Loud et al., 1965). A transparent acetate grid consisting of 63 parallel lines, $180 \mathrm{~mm}$ long and $4 \mathrm{~mm}$ apart, was placed over $8 \times 10$ micrographs of parietal cells with a magnification of $\times 9300$. The area of the cell and area of the nucleus was calculated by placing a metric ruler along the grid lines and tabulating the total distance of the lines enclosed by the cell or nuclear membrane. The total cytoplasmic area of the cells was determined after subtracting the area of the nucleus. Intersections between grid lines of tubulovesicular and canalicular membranes were then counted to determine the percentage of cytoplasmic area occupied by these components. Tangential contacts also were counted. The Loud equation for membrane profile concentration (Loud, 1962; Loud et al., 1965) was then used: $\frac{\pi(C)(M)}{2000(L)}$ where $C=$ number of intersections; $\mathbf{M}=$ magnification of micrographs; $\mathrm{L}=$ area of cell excluding nucleus. For comparison, measurements were also made for control parietal cells (before glucagon) using the Weibel (Weibel et al., 1961; Weibel and Gomez, 1962) grid method for calculating surface area of membrane. This method has been used by a number of investigators (Helander and Hirschowitz, 1972; Zalewsky and Moody, 1977).

Data of quantitative evaluation were analysed statistically by use of the one-way analysis of variance in order to detect subject differences (Snedecor and Cochran, 1967).

\section{Results}

\section{PHYSIOLOGICAL STUDIES}

The results for gastric mucosal PD and gastric $\mathrm{pH}$ are shown in Fig. 1. Glucagon caused a significant $(P<0.001)$ increase in negativity in gastric mucosal PD in all subjects, reaching peak values at 20 minutes and remaining significantly raised throughout the study.

Mean gastric $\mathrm{pH}$ in basal samples was $1 \cdot 8 \pm \mathbf{0} \cdot \mathbf{2}$ (mean $\pm \mathrm{SE}$ ); this increased over the next 15 minutes after glucagon injection to $\mathrm{pH} 2 \cdot 8 \pm 0.65(\mathrm{P}<0.05)$ and remained at this level throughout the study.
ULTRASTRUCTURAL STUDIES

Parietal cells from the normal human gastric gland showed a tubulovesicular and canalicular membrane system that was well developed. Canaliculi were bordered with a moderate number of microvilli. Multi-lobed nuclei in parietal cells were found occasionally in all gastric biopsies examined. The predominant shape of the parietal cells examined was roughly spherical, regardless of level in the gland. However, rectangular, triangular, oval, and irregular cells were found.

After glucagon injection parietal cells (Fig. 2) showed tubulovesicular and canalicular systems similar to those in the normal untreated parietal cell. Nuclei and mitochondria in both normal and glucagon-treated cells appeared similar in size, shape, and density. Dark staining residual bodies, presumably lysosomal in nature, were randomly distributed in similar numbers in treated and untreated cells.

The micrographs of parietal cells before administration of glucagon were analysed morphometrically by both the methods of Weibel (Weibel et al., 1961; Weibel and Gomez, 1962) and Loud (1962) to determine membrane area of tubulovesicular and canalicular components. Because of the irregular cell shape and presence of multi-lobed nuclei, it was felt that the Loud method of determination in twodimensional units (surface area) was preferable in our studies in man to that of Weibel. Weibel requires conversion to three-dimensional units (surface density-surface area per unit of cell volume) and assumes a regular cell shape. The analysis, therefore, was primarily concerned with the percentage of the tubulovesicular and canalicular membrane component per unit of cytoplasmic area.

For comparison, the Table shows data obtained for tubulovesicular and canalicular membrane areas using both the Loud and Weibel grids. No significant difference occurred between values obtained by either method. These results agreed with Weibel's findings for hepatocytes (Weibel et al., 1961), and show that either method can be used with equal validity for morphometric studies of parietal cell membrane area in man.

An analysis of variance for conditions before and after glucagon demonstrated the presence of indivi-

Table Comparison of membrane area expressed as a percentage (mean $\pm S E M)$ as measured by Loud and Weibel methods

\begin{tabular}{llllll}
\hline & \multicolumn{2}{l}{ Tubulovesicles } & & \multicolumn{2}{l}{ Canaliculi } \\
\cline { 2 - 3 } & Loud & Weibel & & Loud & Weibel \\
\hline Normal saline & $100 \pm 8$ & $100 \pm 9$ & & $100 \pm 6$ & $100 \pm 7$ \\
\hline
\end{tabular}

There were no significant differences between vesicular or canalicular values obtained by either method. 


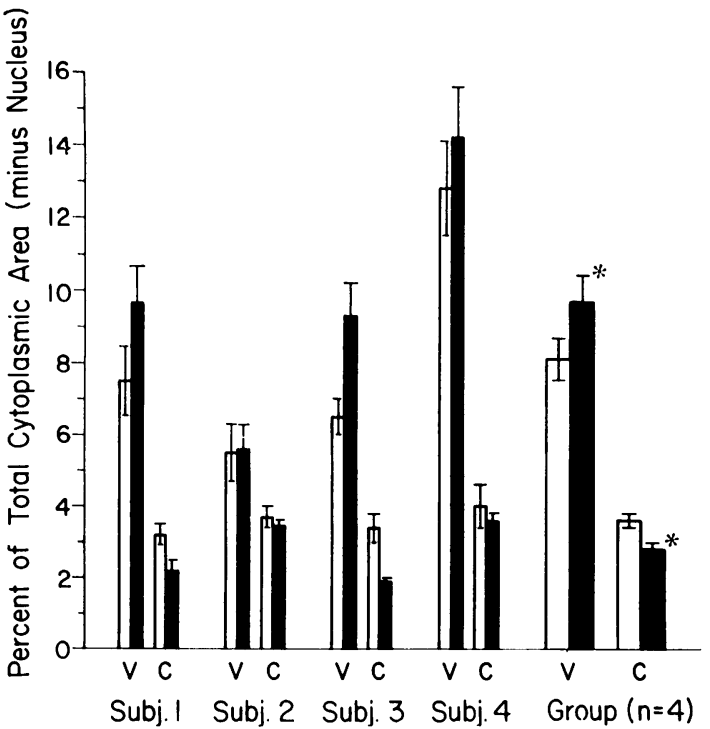

Fig. 3 The area of the tubulovesicular $(V)$ and canalicular $(C)$ systems of parietal cells before and after glucagon treatment are expressed as a percentage of the total cytoplasmic area (minus nucleus). A statistically significant decrease in canalicular membrane area with a simultaneous significant increase in tubolovesicular area was observed 20 minutes after intravenous injection of glucagon. ${ }^{*} \mathrm{P}<0.05 . \square$ Control. $\square$ Glucagon.

dual differences in canalicular and tubulovesicular area among the four subjects studied. Taking these individual differences into account, an analysis of variance was further used to compare the response of canaliculi and tubulovesicules after glucagon injection with those of the normal saline period. This analysis demonstrated a significant decrease in canalicular membrane area $(\mathrm{P}<0.05)$ and a significant increase in tubulovesicular area $(\mathrm{P}<0.05)$ after glucagon. Figure 3 shows the canalicular and tubulovesicular membrane area expressed as a percentage of cytoplasmic area (minus nucleus) in the four subjects before and after glucagon both individually and as a group.

\section{Discussion}

The data show that inhibition of acid secretion by glucagon is associated with a significant reduction in secretory canalicular membrane area in parietal cells. These findings are consistent with the hypothesis of Forte et al. (1977) that the increase in PD caused by $\mathrm{HCl}$ inhibitors could be attributed to a decrease in canalicular membrane area in the parietal cell.

Acid secretion apparently involves secretion of equal amounts of $\mathrm{H}^{+}$and $\mathrm{Cl}^{-}$, superimposed on the basal secretion of $\mathrm{Cl}^{-}$. The basal secretion of $\mathrm{Cl}^{-}$ tends to make the PD of the luminal side of the mucosa negative (Hogben, 1955). Inhibition of acid secretion after glucagon injection involves a significant decrease in total gastric membrane area due to a decrease in canalicular surface area. This may act to shunt the basal $\mathrm{Cl}^{-}$secretion through a much smaller membrane area. Since the current is the same, but the resistance is much higher (resistance is inversely proportional to membrane area), the voltage has to increase by Ohm's law: E (potential difference) $+\mathbf{I}$ (current) $\times \mathbf{R}$ (resistance).

The $\mathrm{H}_{2}$-receptor antagonist, cimetidine, like glucagon (Tarnawski et al., 1978b) causes a significant rise in gastric mucosal PD (Ivey et al., 1975). On the other hand, inhibition of acid secretion by thiocyanate (Schlesinger et al., 1955) or anoxia (Forte et al., 1975) is not followed by an increased negativity of PD. In a stereological analysis of the parietal cell during acid inhibition in dogs, cimetidine reduced secretory membrane surface area during acid inhibition, but thiocyanate did not (Zalewsky and Moody, 1977). Ultrastructurally, therefore, glucagon in this study behaved similarly to the $\mathbf{H}_{2}$-receptor antagonist, cimetidine, rather than to the metabolic inhibitor thiocyanate (Zalewsky and Moody, 1977).

This work was supported in part by the Medical Research Service of the Veterans Administration and the CRC NIH Grant Na RR00287-12. We gratefully acknowledge the advice of Professor Jared Diamond, Department of Physiology, UCLA, and Professor Phillip F. Rust, Department of Statistics, University of Missouri, the assistance of Miss Velma Henthorne in typing the manuscript. This paper was presented in part at the Annual Meeting of the American Gastroenterological Association, Las Vegas, May, 1978.

\section{References}

Andersson, S., and Grossman, M. I. (1965). Profile of pH, pressure and difference at gastroduodenal junction in man. Gastroenterology, 49, 364-371.

Baskin, W. N., Ivey, K. J., Krause, W. J., Jeffrey, G. E., and Gemmell, R. T. (1976). Aspirin-induced ultrastructural changes in human gastric mucosa. Annals of Internal Medicine, 85, 299-303.

Forte, T. M., Machen, T. E., and Forte, J. G. (1975). Ultrastructural and physiological changes in piglet oxyntic cells during histamine stimulation and metabolic inhibition. Gastroenterology, 69, 1208-1222.

Forte, T. M., Machen, T. E., and Forte, J. G. (1977). Ultrastructural changes in oxyntic cells associated with secretory function: a membrane recycling hypothesis. Gastroenterology, 73, 941-955.

Frexinos, J., Carballido, M., Louis, A., and Ribert, A. (1971). Effects of pentagastrin stimulation on human 
parietal cells. An electron microscope study with quantitative evaluation of cytoplasmic structures. American Journal of Digestive Disease, 16, 1065-1074.

Hamer, D. B., Price, A. B., and Baron, J. H. (1977). Morphological and pharmacological studies of the parietal cells of the stomach in the dog during periods of maximal acid output and after the gastric secretory inhibitor UK-9040. Gut, 18, 91-98.

Helander, H. F. (1964). Ultrastructure of gastric fundus glands of re-fed mice. Journal of Ultrastructural Research, 10, 160-175.

Helander, H. F., and Hirschowitz, B. I. (1972). Quantitative ultrastructural studies on gastric parietal cells. Gastroenterology, 63, 951-961.

Helander, H. F., Sanders, S. S., and Rhem, W. S. (1972). Quantitative aspects of gastric morphology, In Gastric Secretion, pp. 69-88. Edited by G. Sachs, E. Heinz, and K. Ullrich, Academic Press: New York.

Hogben, C. A. M. (1955). Active transport of chloride by isolated frog gastric epithelium: origin of the gastric mucosal potential. American Journal of Physiology, 180, 641-649.

Ivey, K. J., Baskin, W. N., and Jeffrey, G. E. (1975). Effect of cimetidine on gastric potential difference in man. Lancet, 2, 1072-1073.

Loud, A. V. (1962). A method for the quantitative estimation of cytoplasmic structures. Journal of Cell Biology, 15, 481-487.

Loud, A. V., Barany, W. C., and Pack, B. A. (1965). Quantitative evaluation of cytoplasmic structures in electron micrographs. Laboratory Investigation, 14, 996-1008.

Luft, J. H. (1961). Improvements in epoxy resin embedding methods. Journal of Biophysical and Biochemical Cytology, 9, 409-414.

Posey, E. L., Jr., Elliott, R., Shewmake, B., and Posey, L., III. (1968). Comparative effect of long-term anticholinergic administration with glycopyrrolate and of vagotomy on parietal cell function, ultrastructure, and population. American Journal of Digestive Disease, $13,515-526$.

Reynolds, E. S. (1963). The use of lead citrate at a high $\mathrm{pH}$ as an electron-opaque stain in electron microscopy. Journal of Cell Biology, 17, 208-212.

Schlesinger, H., Dennis, W. H., and Rehm, W. S. (1955). Effect of thiocyanate on electrophysiological properties of mammalian stomach. American Journal of Physiology, 183, 75-78.

Sedar, A. W. (1962). The fine structure of the oxyntic cell in relation to functional activity of the stomach. Annals of the New York Academy of Sciences, 99, 9-29.

Sedar, A. W., and Friedman, M. H. F. (1961). Correlation of the fine structure of the gastric parietal cell (dog) with functional activity of the stomach. Journal of Biophysical and Biochemical Cytology, 11, 349-363.

Snedecor, G. W., and Cochran, W. E. (1967). Statistical Methods, 6th ed. Ames Iowa State University Press: Iowa.

Spurr, A. R. (1969). A low-viscosity epoxy resin embedding medium for electron microscopy. Journal of Ultrastructural Research, 26, 31-43.

Tarnawski, A., Ivey, K. J., Krause, W. J., and Stachura, J. (1978a). Effect of glucagon on gastric mucosa in man. Potential difference (PD) ultrastructural and histochemical study. Program VI World Congress of Gastroenterology, p. 130.

Tarnawski, A., Krause, W. J., and Ivey, K. J. (1978b). Effect of glucagon on aspirin-induced gastric mucosal damage in man. Gastroenterology, 74, 240-245.

Vial, J. D., and Orrego, H. (1960). Electron microscope observations of the fine structure of parietal cells. Journal of Biophysical and Biochemical Cytology, 7, 367-372.

Vial, J. D., and Orrego, H. (1963). Action of 2,4dinitrophenol and iodoacetate on the ultrastructure of the oxyntic cells. Experimental Cell Research, 30, 232-235.

Watson, M. L. (1958). Staining of tissue sections for electron microscopy with heavy metals. Journal of Biophysical and Biochemical Cytology, 4, 475-478.

Weibel, E. R., and Gomez, D. M. (1962). A principle for counting tissue structures on random sections. Journal of Applied Physiology, 17, 343-348.

Weibel, E. R., Stäubli, W., Gnägi, H. R., and Hess, F. A. (1961). Correlated morphometric and biochemical studies on the liver cell. 1. Morphometric model, stereologic methods and normal morphometric data for rat liver. Journal of Cell Biology, 42, 68-91.

Zalewsky, C. A., and Moody, F. G. (1977). Stereological analysis of the parietal cell during acid secretion and inhibition. Gastroenterology, 73, 66-74. 